\title{
Chemical composition and antimicrobial activity of essential oils from selected herbs cultivated in the South of Brazil against food spoilage and foodborne pathogens
}

\author{
Composição química e atividade antimicrobiana de óleos essenciais de plantas selecionadas cultivadas no \\ Sul do Brasil contra micro-organismos patogênicos e deteriorantes de alimentos
}

\author{
Sheila Mello da Silveira ${ }^{\mathrm{I}, \mathrm{II}}$ Anildo Cunha Júnior ${ }^{\mathrm{III}}$ Gerson Neudí Scheuermann"II \\ Fábio Luiz Secchi ${ }^{I}$ Cleide Rosana Werneck Vieira ${ }^{I^{*}}$
}

\begin{abstract}
The chemical composition of 10 selected plant essential oils obtained by steam distillation was determined by GC and GC/MS. The antimicrobial activity of the essential oils was screened against 12 important food-related bacterial strains by agar disc-diffusion assay. MIC and MBC were determined for the essential oils that presented the highest activity in the agar disc-diffusion test. The most active essential oils against the tested bacteria were, in descending order, lemongrass (Cymbopogon flexuosus), basil (Ocimum basilicum), oregano (Origanum vulgare), cinnamon leaf (Cinnamomum zeylanicum), and laurel (Laurus nobilis). Except for $\boldsymbol{S}$. Typhimurium, the tested bateria were inhibited at MIC values lower or equal to $0.62 \mathrm{mg} \mathrm{mL}^{-1}$ by lemongrass (Cymbopogon flexuosus) essential oil. Yersinia enterocolitica presented the highest sensitivity to all essential oils tested $\left(C M I \leq 0.62 \mathrm{mg} \mathrm{mL}^{-1}\right)$. There was a significant correlation $(P<0.05)$ between oxygenated monoterpenes levels in the essential oils and MIC and MBC values against Escherichia coli. Results showed that the evaluated essential oils present high potential as natural preservatives.
\end{abstract}

Key words: essential oils, chemical composition, phytotherapic agents, antibacterial activity, food pathogens.

\section{RESUMO}

A composição química de 10 óleos essenciais obtidos por destilação a vapor foi determinada por CG/DIC e CG/EM. A atividade antimicrobiana dos óleos essenciais foi detectada através do método de difusão em ágar frente a 12 espécies de bactérias de importância em alimentos. As CMI e $C M B$ foram determinadas para os óleos essenciais que na difusão em ágar evidenciaram maior atividade. Os óleos essenciais que apresentaram maior atividade contra as bactérias testadas foram, em ordem decrescente, os de capim-limão (Cymbopogon flexuosus), manjericão (Ocimum basilicum), orégano (Origanum vulgare), folha de canela (Cinnamomum zeylanicum) e louro (Laurus nobilis). Com exceção de $\boldsymbol{S}$. Typhimurium, o óleo essencial de capim limão (Cymbopogon flexuosus) apresentou valores de CMI e CMB iguais ou inferiores a 0,62 $\mathrm{mg} \mathrm{mL}^{-1}$ contra os micro-organismos testados. Yersinia enterocolitica foi o patógeno mais sensível frente a todos os óleos essenciais avaliados $\left(C M I \leq 0,62 \mathrm{mg} \mathrm{mL}^{-1}\right)$. Foi detectada correlação significativa $(P<0,05)$ entre os níveis de monoterpenos oxigenados dos óleos essenciais e os valores de CMI e CMB contra Escherichia coli. Os resultados demonstram que os óleos essenciais avaliados apresentam grande potencial como agentes antimicrobianos naturais para alimentos.

Palavras-chave: óleos essenciais, composição química, fitoterápicos, atividade antibacteriana, patógenos alimentares.

\section{INTRODUCTION}

There has recently been considerable concern with the increasing incidence of foodborne diseases, which have become relevant public health issues (OUSSALAH et al., 2007). In spite of the advances in the sanitation techniques and inspection services, the contamination of foods with undesirable microorganisms is a potential risk during food processing, further processing, storage and distribution both in developing and developed

Instituto Federal Catarinense (IFC), Campus Concórdia, Concórdia, SC, Brasil.

"Departamento de Ciência e Tecnologia de Alimentos, Universidade Federal de Santa Catarina (UFSC), 88034-001, Florianópolis, SC, Brasil. E-mail: cleiderosana@cca.ufsc.br*Autor para correspondência.

IIIEmbrapa Suínos e Aves, Concórdia, SC, Brasil. 
countries (RUNYORO et al., 2010). As pathogens resistant to classic preservatives have been detected, alternative antimicrobial agents need to be urgently found (MILITELLO et al., 2011).

During the last few years, the utilization of natural food preservatives has been widely accepted by the consumers, who increasingly seek natural and healthy products, containing less synthetic additives. Consumers are used to the presence of spices in food products that are mainly used to enhance taste and flavor, and therefore, essential oils derived from spices applied as natural food preservatives should not cause any rejection (MILITELLO et al., 2011).

The reported antimicrobial activity of essential oils derived from a same plant species is often very different. Different geographic locations where plants are grown, harvest time, genotype, and weather conditions during growth and harvest (CELIKTAS et al., 2007; OUSSALAH et al., 2007) account for these differences, and therefore, the composition and the activity of essential oils obtained from plants grown in a determined region need to be characterized.

The aim of the present study was to determine the chemical composition of essential oils obtained from 10 exotic plant species cultivated in the south of Brazil and to evaluate their antimicrobial activity against 12 bacterial species that may cause food poisoning and spoilage. Data obtained in this study could aid the identification of potential essential oils to be applied as food preservatives.

\section{MATERIAL AND METHODS}

Plant materials and essential oils

Essential oils from the following plant species were tested in this work: basil (Ocimum basilicum), cinnamon (Cynnamomum zeylanicum), fennel (Foeniculum vulgare), laurel (Laurus nobilis), lemongrass (Cymbopogon winterianus), mint (Mentha arvensis), pennyroyal (Mentha pulegium), orange (Citrus sinensis), oregano (Origanum vulgare), and rosemary (Rosmarinus officinalis).

The plant materials were collected in Concórdia, state of Santa Catarina, Brazil $\left(27^{\circ} 14^{\prime} 2^{\prime \prime}{ }^{\circ} \mathrm{S}\right.$, $\left.52^{\circ} 1^{\prime} 40^{\prime \prime} \mathrm{W}\right)$, between October, 2009 and April, 2010. The plants were identified by Drs. S. J. Longui and A. R. T. Nascimento (Federal University of Santa Maria UFSM, RS, Brazil) and by Dr. André Jasper (Univates, RS, Brazil). The voucher specimens (Table 1) are deposited at the Forest Herbarium of the Dendrology Laboratory of the Forest Sciences Department of UFSM (HDCF) and at the Herbarium of the Museum of Natural Sciences of the Department of Botany and Paleobotany of Univates (HVAT). All essential oil samples were obtained by steam-distillation of the aerial parts of the plants using a pilot-scale apparatus and were stored at $4^{\circ} \mathrm{C}$.

Gas chromatography (GC/FID)

Gas chromatography was performed in a chromatograph GC Varian CP-3800. ARtx-5MS fused silica capillary column $(30 \mathrm{mx} 0.25 \mathrm{~mm}, 0.25 \mu \mathrm{m}$ film thickness, $5 \%$ diphenyl $/ 95 \%$ dimethyl polysiloxane) was employed for separation. Samples were analyzed in triplicate.

Gas chromatography/mass spectrometry (GC/MS)

Gas chromatography/mass spectrometry analyses were performed in a gas chromatograph coupled to mass spectrometer (Shimadzu GCMSQP2010) using a Rtx-5MS fused silica capillary column $(30 \mathrm{~m} \times 0.25 \mathrm{~mm} ; 0.25 \mu \mathrm{m}$ film thickness, composed of $5 \%$ phenylmethylpolysiloxane).

Detection of antimicrobial activity - Agar disc-diffusion assay

The essential oils were tested against 12 bacterial strains: Staphylococcus aureus ATCC 25923, Lactobacillus plantarum ATCC 8014, Listeria monocytogenes ATCC 19117, Enterococcus faecalis ATCC 29212, Bacillus cereus ATCC 11778, Bacillus subtilis ATCC 6633, Escherichia coli ATCC 25922, Salmonella Typhimurium ATCC 14028, Proteus vulgaris ATCC 13315, Enterobacter aerogenes ATCC 13048, Pseudomonas aeruginosa ATCC 27853 and Yersinia enterocolitica ATCC 9610. The detection of inhibitory effect of the essential oils on the tested bacteria was carried out by agar disc-diffusion method based on the document M2-A8 of CLSI (2003a). Sterile paper discs $\left(9 \mathrm{~mm}\right.$ in diameter and $\left.250 \mathrm{~g} \mathrm{~m}^{-2}\right)$ were impregnated with $25 \mu \mathrm{L}$ of pure essential oil, and placed on plates inoculated with $10^{7}$ suspensions of each culture, which were then incubated at $36^{\circ} \mathrm{C}$ for $18-24 \mathrm{~h}$. Commercial ampicillin $\left(10 \mu \mathrm{g} \mathrm{disc}^{-1}\right)$ and chloramphenicol $\left(30 \mu \mathrm{g} \mathrm{disc}^{-1}\right)$ discs were used as reference antibiotics. The diameter of inhibition zones, including the disc diameter, was measured in millimeters, and inhibition was scored as weak (10-13,9mm), moderate (14-18mm), or strong $(>18 \mathrm{~mm})$ according to Carovic-Stanko (2010). Tests were performed in quadruplicate.

Determination of Minimum Inhibitory Concentration (MIC) and Minimum Bactericidal Concentration (MBC)

The minimum inhibitory concentration (MIC) of the most active essential oils against six bacterial strains was determined using the microdilution broth method, based on the document M7-A6 of CLSI 
Table 1 - Plant species, voucher numbers and main constituents of the respective essential oils, as determined by gas chromatography (CGFID and CG-MS). ${ }^{a}$

\begin{tabular}{|c|c|c|c|}
\hline Common name & Plant species & Voucher $^{b}$ & Main compounds $(\%, \mathrm{RIE})^{c}$ \\
\hline Basil & Ocimum basilicum L. & HVAT 2603 & $\begin{array}{l}\text { Linalool }(35.57,1102) ; \quad 1,8 \text {-Cineole }(16.42,1028) \text {; } \\
\text { Eugenol }(11.31,1360) \text {; Camphor }(9.98,1141)\end{array}$ \\
\hline Cinnamon $^{d}$ & $\begin{array}{l}\text { Cynnamomum zeylanicum } \\
\text { Blume }\end{array}$ & HDCF 5538 & $\begin{array}{l}\text { 1,8-Cineole }(22.64,1028) ; o \text {-Cymene }(19.35,1022) ; \alpha \text { - } \\
\text { Phellandrene }(9.98,1003) ; \alpha \text {-Pinene }(5.24,929)\end{array}$ \\
\hline Fennel & Foeniculum vulgare Mill & HVAT 2610 & trans-Anethole $(80.92,1287) ; \alpha$-Pinene $(5.07,929)$ \\
\hline Laurel & Laurus nobilis L. & HDCF 5536 & $\begin{array}{l}\text { 1,8-Cineole }(35.50,1028) ; \text { Linalool }(14.10,1102) ; \alpha \text { - } \\
\text { Terpinyl acetate }(9.65,1349) \text {; Sabinene }(9.45,970)\end{array}$ \\
\hline Lemongrass & $\begin{array}{l}\text { Cymbopogon flexuosus } \\
\text { (DC) Stapf }\end{array}$ & HVAT 2613 & $\begin{array}{l}\text { Geranial }(38.68,1274) \text {; Neral }(28.46,1238) ; \beta \text {-Myrcene } \\
(8.79,990)\end{array}$ \\
\hline Mint & Mentha arvensis $\mathrm{L}$. & HVAT 2602 & Menthol $(86.05,1175)$; p-Menthan-3-one $(3.44,1152)$ \\
\hline Pennyroyal & Mentha pulegium L. & HVAT 2611 & $\begin{array}{l}\beta \text {-Caryophyllene }(25.67,1413) \text {; Germacrene D (12.55, } \\
\text { 1476); Isomenthol }(9.37,1165) \text {; Germacrene B (6.86, } \\
\text { 1492); Isomenthone }(5.61,1163)\end{array}$ \\
\hline Orange $^{d}$ & Citrus sinensis & HVAT 2613 & $\begin{array}{l}\text { Sabinene }(47.72,970) ; \text { Linalool }(7.66,1102) ;(E)-\beta \text { - } \\
\text { Ocimene }(6.33,1047) \text {; Citronellal }(5.46,1153)\end{array}$ \\
\hline Oregano & Origanum vulgare L. & HVAT 2614 & $\begin{array}{l}\gamma \text {-Terpinene }(31.68,1056) ;(Z) \text { - } \beta \text {-Ocimene }(16.03,1038) \text {; } \\
(E)-\beta \text {-Ocimene }(11.68,1047) ; o \text {-Cymene }(11.43,1022)\end{array}$ \\
\hline Rosemary & Rosmarinus officinalis L. & HVAT 2600 & $\begin{array}{l}\text { Camphor }(24.02,1141) ; 1,8 \text {-Cineole }(14.24,1028) ; \beta \text { - } \\
\text { Myrcene }(12.50,990) ; \alpha \text {-Pinene }(9.85,929) ; \beta \text {-Pinene } \\
(6.99,972)\end{array}$ \\
\hline
\end{tabular}

${ }^{a}$ All essential oils were obtained by steam distillation of the aerial parts of the plants.

${ }^{b}$ HVAT: Herbarium of the Natural Sciences Museum of the Department of Botany and Paleobotany, Univates (RS, Brazil); HDCF: Forest herbarium of the Dendrology Laboratory of the Forest Sciences Department (UFSM, RS, Brazil).

${ }^{c}$ Results expressed as \% relative to peak area and Retention Index (RIE) experimentally determined on Rtx-5MS column using homologous series of $\mathrm{C}_{7}-\mathrm{C}_{30}$ alkanes.

${ }^{d}$ Cinnamon and orange essential oils were obtained from the plant leaves.

(2003b). The essential oils were diluted to $100 \mathrm{mg} \mathrm{mL}^{-1}$ in dimethylsulfoxide (DMSO). A series of twofold dilutions of each individual essential oil, ranging from $10 \mathrm{mg} \mathrm{mL}^{-1}$ to $0.075 \mathrm{mg} \mathrm{mL}^{-1}$, was tested. Minimal bactericidal concentration (MBC) was determined from the microdilution plates used in the MIC assay, according to CELIKTAS et al. (2007), with modifications. Aliquots $(10 \mu \mathrm{L})$ of each well without visible growth were transferred to TSA plates, incubated at $36^{\circ} \mathrm{C}$ for $24 \mathrm{~h}$ and colony growth was verified. All assays were performed in triplicate.

\section{Statistics}

Analysis of variance (Anova) was performed $(\mathrm{P}<0.05)$ for each bacterial species (agar disc-diffusion assay) and differences between means were determined by Tukey's HSD test $(\mathrm{P}<0.05)$. Spearman's coefficient of correlation was calculated $(\mathrm{P}<0.05)$ between the main groups of components identified in the essential oils and inhibition areas for each bacterial species, as well as between components and MIC and MBC values obtained for each bacterial species, using the CORR procedure of SAS statistical package (SAS, 2003).

\section{RESULTS AND DISCUSSION}

The main constituents of the studied essential oils are presented in table 1 . The analysis allowed the identification of 89 compounds, accounting for 81.41 to $99.41 \%$ of the composition of volatile 
substances (data not shown). Tables 2 and 3 show the antimicrobial activity of the essential oils as determined by the agar disc-diffusion test. All evaluated essential oils presented antimicrobial activity against different bacterial species, but at different intensities. The essential oils presenting the strongest antimicrobial activity and broadest range of action were, in descending order, lemongrass, basil, oregano, cinnamon leaf, laurel, and rosemary. MIC and $\mathrm{MBC}$ values of these essential oils against six bacterial species are shown in table 4. MIC values ranged between 0.075 and $10 \mathrm{mg} \mathrm{mL}^{-1}$, and $\mathrm{MBC}$ values, between 0.31 and $>10 \mathrm{mg} \mathrm{mL}^{-1}$.

In the agar disc-diffusion test, lemongrass essential oil strongly inhibited all tested Gram-positive bacteria and presented higher activity on $\boldsymbol{S}$. aureus as compared to ampicillin. Among the Gram-negative bacteria, it presented strong inhibition of $\boldsymbol{S}$. Typhimurium, Y. enterocolitica and $\boldsymbol{P}$. vulgaris, and moderately inhibited $\boldsymbol{E}$. coli. The inhibition areas are similar to those observed by WANNISSORN et al. (2005) for the essential oil of the lemongrass species Cymbopogon citratus. The strong antibacterial activity of lemongrass essential oil was confirmed by the lowest MIC and MBC values $\left(\leq 1.25 \mathrm{mg} \mathrm{mL}^{-1}\right)$ observed against all tested microorganisms. It was the most efficient of the evaluated essential oils, particularly against $\boldsymbol{S}$. aureus, B. cereus, L. monocytogenes, $E$. coli and $S$. Typhimurium, important pathogen strains and foodquality indicators. This essential oil consisted mainly of neral and geranial isomers, which have considerable antimicrobial activity against Gram-positive and Gramnegative bacteria (ONAWUNMI, 1989).

Basil essential oil presented strong inhibitory action against all tested Gram-positive bacteria. It also showed high activity against $\boldsymbol{Y}$. enterocolitica, $\boldsymbol{P}$. vulgaris and $\boldsymbol{E}$. coli. This essential oil also presented strong to moderate inhibition (MIC and $\mathrm{MBC} \leq 2.5 \mathrm{mg} \mathrm{mL}^{-1}$ ) of the microorganisms used in the microdilution test, and was the second most active of the essential oils evaluated. Basil essential oil was characterized by the presence of linalool, 1,8-cineole and eugenol, which are active against both Grampositive and Gram-negative bacteria (WALSH et al., 2003; SOKOVIC et al., 2007). RUNYORO et al. (2010) reported weak to moderate activity of that essential oil (MIC between 10.7 and $12.5 \mathrm{mg} \mathrm{mL}^{-1}$ against $S$. aureus and between 3.14 and $4.25 \mathrm{mg} \mathrm{mL}^{-1}$ against $\boldsymbol{E}$. coli) for two evaluated basil samples that were poor in linalool and eugenol. This stresses the importance of evaluating the biological activity of plants cultivated in different regions and under different conditions.

Laurel essential oil strongly inhibited $\boldsymbol{E}$. coli and was also active against the other Gram-negative bacteria tested, except for P. aeruginosa. In the MIC/ $\mathrm{MBC}$ assays, laurel essential oil presented strong to moderate activity ( $\left.\mathrm{MIC} \leq 5 \mathrm{mg} \mathrm{mL}^{-1}\right)$ against all tested microorganisms, except for $\boldsymbol{S}$. aureus. It was the third best essential oil evaluated for inhibition of Gramnegative bacteria tested. Although presenting different

Table 2 - Antimicrobial activity of the evaluated essential oils against food-related microorganisms, as detected in the agar disc-diffusion test $(\mathrm{mm})^{a}$.

\begin{tabular}{|c|c|c|c|c|c|c|c|}
\hline & Basil & Cinnamon $^{b}$ & Fennel & Laurel & Lemongrass & Ampicilin & Chlor. ${ }^{c}$ \\
\hline S.aureus & $20.5 \pm 0.4^{f g}$ & $17.4 \pm 0.2^{\text {hi }}$ & $12.1 \pm 0.5^{\mathrm{j}}$ & $18.9 \pm 0.5^{\text {gh }}$ & $50.5 \pm 1.7 \mathrm{a}$ & $36.4 \pm 1.8^{b}$ & $26.1 \pm 0.5^{\mathrm{cc}}$ \\
\hline E.faecalis & $19.2 \pm 0.6^{\mathrm{c}}$ & $14.6 \pm 0.6^{\mathrm{ef}}$ & $11.8 \pm 0.3^{g}$ & $13.6 \pm 0.7^{\mathrm{f}}$ & $24.7 \pm 0.9 b$ & $27.0 \pm 0.4^{\mathrm{a}}$ & $23.6 \pm 0.2^{b}$ \\
\hline L.monocytogenes & $19.0 \pm 0.7^{\mathrm{e}}$ & $15.2 \pm 0.3^{\mathrm{fg}}$ & $12.5 \pm 0.4^{\mathrm{g}}$ & $21.4 \pm 0.8^{\mathrm{e}}$ & $52.1 \pm 1.2^{\mathrm{a}}$ & $31.1 \pm 0.9^{b}$ & $28.4 \pm 1.0^{b c}$ \\
\hline L.plantarum & $26.1 \pm 1.2^{b c}$ & $22.0 \pm 1.8^{\mathrm{de}}$ & $13.8 \pm 0.6^{\mathrm{hi}}$ & $0.0 \pm 0.0^{j}$ & $23.2 \pm 0.9^{\mathrm{cd}}$ & $32.0 \pm 0.9^{\mathrm{a}}$ & $29.2 \pm 1.0^{\mathrm{at}}$ \\
\hline B.cereus & $20.1 \pm 1.1^{\mathrm{d}}$ & $21.2 \pm 0.9^{\mathrm{d}}$ & $16.0 \pm 0.4^{\mathrm{ef}}$ & $20.2 \pm 0.6^{\mathrm{d}}$ & $42.7 \pm 1.5^{\mathrm{a}}$ & $12.1 \pm 0.2^{\mathrm{g}}$ & $27.9 \pm 0.7^{\mathrm{c}}$ \\
\hline B.subtilis & $21.1 \pm 0.8^{\mathrm{e}}$ & $19.0 \pm 0.4^{\mathrm{ef}}$ & $13.1 \pm 0.5^{\mathrm{h}}$ & $31.4 \pm 0.6^{\mathrm{d}}$ & $42.2 \pm 4.0^{b}$ & $31.1 \pm 1.8^{\mathrm{d}}$ & $29.9 \pm 0.5^{\mathrm{d}}$ \\
\hline Y.enterocolitica & $45.3 \pm 2.0^{\mathrm{a}}$ & $14.0 \pm 0.0^{\mathrm{g}}$ & $11.8 \pm 0.3^{\mathrm{g}}$ & $14.0 \pm 0.9^{g}$ & $30.1 \pm 1.2^{b}$ & $21.7 \pm 0.5^{\mathrm{e}}$ & $28.1 \pm 0.5^{b c}$ \\
\hline E.coli & $21.6 \pm 1.1^{\mathrm{c}}$ & $11.5 \pm 0.0^{\mathrm{g}}$ & $11.1 \pm 0.2^{\mathrm{g}}$ & $24.5 \pm 0.7^{b}$ & $17.2 \pm 0.3^{\mathrm{e}}$ & $18.9 \pm 0.5^{\mathrm{d}}$ & $26.1 \pm 0.6^{\mathrm{a}}$ \\
\hline S.Typhimurium & $12.9 \pm 0.2^{\mathrm{d}}$ & $10.4 \pm 0.2^{\mathrm{e}}$ & $0.0 \pm 0.0^{\mathrm{f}}$ & $10.9 \pm 0.5^{\mathrm{e}}$ & $18.2 \pm 0.5^{\mathrm{c}}$ & $27.1 \pm 0.5^{\mathrm{a}}$ & $24.4 \pm 0.5^{b}$ \\
\hline E.aerogenes & $13.9 \pm 0.5^{b}$ & $10.5 \pm 0.4^{\mathrm{c}}$ & $0.0 \pm 0.0^{\mathrm{d}}$ & $11.0 \pm 0.4^{\mathrm{c}}$ & $13.9 \pm 1.9^{b}$ & $0.0 \pm 0.0^{\mathrm{d}}$ & $23.0 \pm 0.7^{\mathrm{a}}$ \\
\hline P.vulgaris & $34.6 \pm 0.5^{b}$ & $16.5 \pm 0.7^{\mathrm{fg}}$ & $19.0 \pm 0.4^{\text {ef }}$ & $31.7 \pm 2.2^{b}$ & $40.9 \pm 1.6^{\mathrm{a}}$ & $21.1 \pm 1.0^{\mathrm{de}}$ & $22.4 \pm 0.8^{\mathrm{d}}$ \\
\hline P.aeruginosa & $0.0 \pm 0.0^{\mathrm{c}}$ & $0.0 \pm 0.0^{\mathrm{c}}$ & $0.0 \pm 0.0^{\mathrm{c}}$ & $0.0 \pm 0.0^{\mathrm{c}}$ & $13.6 \pm 0.2^{\mathrm{a}}$ & $0.0 \pm 0.0^{\mathrm{c}}$ & $0.0 \pm 0.0^{\mathrm{c}}$ \\
\hline
\end{tabular}

${ }^{a}$ Inhibition area including $9 \mathrm{~mm}$ disc diameter, expressed as the mean of four replicates \pm SD. Inhibition degrees: $10-13,9 \mathrm{~mm}$ : weak; $14-$ $18 \mathrm{~mm}$ : moderate; $>18 \mathrm{~mm}$ : strong. Means followed by the same letter in the same row are not significantly different $(\mathrm{P}<0.05)$

${ }^{b}$ Cinnamon oil were obtained from the plant leaves.

${ }^{c}$ Chloranphenicol. 
Table 3 - (Table 2 continued). Antimicrobial activity of the evaluated essential oils against food-related microorganisms, as detected in the agar disc-diffusion test $(\mathrm{mm})^{a}$.

\begin{tabular}{|c|c|c|c|c|c|c|c|}
\hline & Mint & Pennyroyal & Orange $^{b}$ & Oregano & Rosemary & Ampicilin & Chlor. $^{c}$ \\
\hline S.aureus & $25.1 \pm 1.4^{\mathrm{de}}$ & $16.0 \pm 0.4^{\mathrm{i}}$ & $21.5 \pm 1.1^{\mathrm{f}}$ & $22.9 \pm 1.0^{\text {ef }}$ & $28.2 \pm 0.9^{\mathrm{c}}$ & $36.4 \pm 1.8^{b}$ & $26.1 \pm 0.5^{\mathrm{cd}}$ \\
\hline E.faecalis & $14.1 \pm 0.5^{f}$ & $13.7 \pm 0.6^{f}$ & $17.1 \pm 0.5^{\mathrm{d}}$ & $16.0 \pm 0.7^{\mathrm{de}}$ & $14.9 \pm 0.7^{\text {ef }}$ & $27.0 \pm 0.4^{\mathrm{a}}$ & $23.6 \pm 0.2^{b}$ \\
\hline L.monocytogenes & $15.4 \pm 1.3^{\mathrm{f}}$ & $13.9 \pm 0.6^{\mathrm{fg}}$ & $21.2 \pm 2.7^{\mathrm{e}}$ & $25.4 \pm 1.3^{\mathrm{d}}$ & $26.5 \pm 1.4^{\mathrm{cd}}$ & $31.1 \pm 0.9^{\mathrm{b}}$ & $28.4 \pm 1.0^{\mathrm{bc}}$ \\
\hline L.plantarum & $19.6 \pm 0.9^{\text {ef }}$ & $24.0 \pm 2.3^{\mathrm{cd}}$ & $14.1 \pm 0.6^{\mathrm{hi}}$ & $17.4 \pm 1.1^{\mathrm{fg}}$ & $12.1 \pm 0.5^{\mathrm{i}}$ & $32.0 \pm 0.9^{\mathrm{a}}$ & $29.2 \pm 1.0^{\mathrm{ab}}$ \\
\hline B.cereus & $21.4 \pm 1.7^{\mathrm{d}}$ & $17.1 \pm 0.2^{\mathrm{e}}$ & $33.1 \pm 1.2 \mathrm{~b}$ & $26.2 \pm 0.6^{\mathrm{c}}$ & $26.4 \pm 0.5^{\mathrm{c}}$ & $12.1 \pm 0.2^{\mathrm{g}}$ & $27.9 \pm 0.7^{c}$ \\
\hline B.subtilis & $21.1 \pm 0.8^{\mathrm{e}}$ & $17.7 \pm 0.9^{\mathrm{fg}}$ & $85.0 \pm 0.0^{\mathrm{a}}$ & $18.0 \pm 1.7^{\mathrm{efg}}$ & $36.0 \pm 0.6^{c}$ & $31.1 \pm 1.8^{\mathrm{d}}$ & $29.9 \pm 0.5^{\mathrm{d}}$ \\
\hline Y.enterocolitica & $24.7 \pm 1.8^{\mathrm{d}}$ & $0.0 \pm 0.0^{\mathrm{h}}$ & $26.7 \pm 1.5^{\mathrm{cd}}$ & $18.9 \pm 1.2^{f}$ & $16.7 \pm 0.5^{f}$ & $21.7 \pm 0.5^{\mathrm{e}}$ & $28.1 \pm 0.5^{b c}$ \\
\hline E.coli & $0.0 \pm 0.0^{\mathrm{h}}$ & $0.0 \pm 0.0^{\mathrm{h}}$ & $0.0 \pm 0.0^{\mathrm{h}}$ & $14.5 \pm 0.4^{\mathrm{f}}$ & $12.2 \pm 0.3^{\mathrm{g}}$ & $18.9 \pm 0.5^{\mathrm{d}}$ & $26.1 \pm 0.6^{\mathrm{a}}$ \\
\hline S.Typhimurium & $0.0 \pm 0.0^{\mathrm{f}}$ & $0.0 \pm 0.0^{\mathrm{f}}$ & $0.0 \pm 0.0^{\mathrm{f}}$ & $12.0 \pm 0.8^{\mathrm{d}}$ & $10.5 \pm 0.0^{\mathrm{e}}$ & $27.1 \pm 0.5^{\mathrm{a}}$ & $24.4 \pm 0.5^{b}$ \\
\hline E.aerogenes & $0.0 \pm 0.0^{\mathrm{d}}$ & $0.0 \pm 0.0^{\mathrm{d}}$ & $0.0 \pm 0.0^{\mathrm{d}}$ & $11.4 \pm 0.5^{\mathrm{c}}$ & $10.2 \pm 0.3^{c}$ & $0.0 \pm 0.0^{\mathrm{d}}$ & $23.0 \pm 0.7^{\mathrm{a}}$ \\
\hline P.vulgaris & $41.5 \pm 2.1^{\mathrm{a}}$ & $0.0 \pm 0.0^{\mathrm{h}}$ & $27.7 \pm 3.0^{\mathrm{c}}$ & $23.7 \pm 0.6^{\mathrm{d}}$ & $14.9 \pm 2.3^{g}$ & $21.1 \pm 1.0^{\mathrm{de}}$ & $22.4 \pm 0.8^{\mathrm{de}}$ \\
\hline P.aeruginosa & $0.0 \pm 0.0^{\mathrm{c}}$ & $0.0 \pm 0.0^{\mathrm{c}}$ & $0.0 \pm 0.0^{\mathrm{c}}$ & $12.7 \pm 0.5^{b}$ & $0.0 \pm 0.0^{\mathrm{c}}$ & $0.0 \pm 0.0^{\mathrm{c}}$ & $0.0 \pm 0.0^{c}$ \\
\hline
\end{tabular}

${ }^{a}$ Inhibition area including $9 \mathrm{~mm}$ disc diameter, expressed as the mean of four replicates \pm SD. Inhibition degrees: $10-13,9 \mathrm{~mm}$ : weak; $14-$ $18 \mathrm{~mm}$ : moderate; $>18 \mathrm{~mm}$ : strong. Means followed by the same letter in the same row are not significantly different $(\mathrm{P}<0.05)$.

${ }^{b}$ Orange oil were obtained from the plant leaves.

${ }^{c}$ Chloranphenicol.

proportions when compared to basil essential oil, 1,8cineole and linalool were also the main compounds identified in laurel essential oil. ERKMEN \& ÖZCAN (2008) evaluated the antimicrobial activity of a laurel essential oil, containing approximately $60 \% 1,8$-cineole and only traces of linalool, and reported lower MIC and $\mathrm{MBC}$ values than those found in the present study against the Gram-positive species $\boldsymbol{S}$. aureus and $\boldsymbol{L}$. monocytogenes, and similar values against $B$. cereus (MIC and MBC of 2.0 and $10.0 \mathrm{mg} \mathrm{mL}^{-1}$, respectively). However, there was no activity against the same $\boldsymbol{E}$. coli and $\boldsymbol{S}$. Typhimurium ATCC strains evaluated in the present study, demonstrating that essential oils with different chemical composition usually present different antimicrobial activity profiles.
Oregano and cinnamon leaf essential oils presented moderate activity against most evaluated bacteria. The obtained MIC values for oregano essential oil against $\boldsymbol{E}$. coli and $\boldsymbol{S}$. Typhimurium were lower than those reported by PEÑALVER et al. (2005), who evaluated the antimicrobial activity of five essential oils against Salmonella species and E. coli isolated from pigs and poultry.

Rosemary essential oil presented higher MIC and MBC values against S. aureus, $L$. monocytogenes and $B$. cereus than the other evaluated essential oils, despite the strong inhibition of these bacterial species detected in the agar disc-diffusion test. These results are consistent with those of

Table 4 - Minimum inhibitory concentration (MIC) and minimum bactericidal concentration (MBC) of the most active essential oils against selected food-related microorganisms $\left(\mathrm{mg} \mathrm{mL}^{-1}\right)^{a}$.

\begin{tabular}{|c|c|c|c|c|c|c|c|c|c|c|c|c|}
\hline & \multicolumn{4}{|c|}{-------Basil-------- ----Cinnamon ${ }^{b}$---- } & \multicolumn{2}{|c|}{-------Laurel------- } & \multicolumn{2}{|c|}{----Lemongrass---- } & \multicolumn{2}{|c|}{-----Oregano------ } & \multicolumn{2}{|c|}{-----Rosemary----- } \\
\hline & $\mathrm{MIC}$ & $\mathrm{MBC}$ & $\mathrm{MIC}$ & $\mathrm{MBC}$ & MIC & $\mathrm{MBC}$ & MIC & $\mathrm{MBC}$ & $\mathrm{MIC}$ & $\mathrm{MBC}$ & $\mathrm{MIC}$ & $\mathrm{MBC}$ \\
\hline S.aureus & 2.5 & 2.5 & 5.0 & 10.0 & 10.0 & $>10.0$ & 0.31 & 0.31 & 5.0 & 5.0 & 10.0 & $>10.0$ \\
\hline L.monocytogenes & 1.25 & 2.5 & 2.5 & 5.0 & 2.5 & 10.0 & 0.62 & 0.62 & 2.5 & 10.0 & 2.5 & $>10.0$ \\
\hline B.cereus & 1.25 & 1.25 & 2.5 & 5.0 & 5.0 & 5.0 & 0.15 & 0.31 & 2.5 & 2.5 & 5.0 & 10.0 \\
\hline Y.enterocolitica & 0.075 & 0.15 & 0.075 & 1.25 & 0.62 & 0.62 & 0.075 & 0.31 & 0.075 & 2.5 & 0.075 & 1.25 \\
\hline E.coli & 1.25 & 1.25 & 5.0 & 10.0 & 2.5 & 2.5 & 0.62 & 0.62 & 5.0 & 10.0 & 2.5 & 5.0 \\
\hline S.Typhimurium & 2.5 & 2.5 & 5.0 & 10.0 & 5.0 & 10.0 & 1.25 & 1.25 & 5.0 & 10.0 & 10.0 & $>10.0$ \\
\hline
\end{tabular}

${ }^{a}$ Tests were performed in triplicate and modal values are presented.

${ }^{b}$ Cinnamon oil were obtained from the plant leaves. 
CELIKTAS et al. (2007), who obtained MIC and MBC values in rosemary essential oil against $\boldsymbol{S}$. aureus between 5 and $20 \mathrm{mg} \mathrm{mL}^{-1}$ and between 10 and $>20 \mathrm{mg}$ $\mathrm{mL}^{-1}$, respectively.

Fennel, pennyroyal, orange leaf, and mint essential oils were in general less active than the other evaluated essential oils. However, some peculiarities should be mentioned, such as the strong activities of mint essential oil against $\boldsymbol{P}$. vulgaris and of pennyroyal against $\boldsymbol{L}$. plantarum as well as the exceptional activity of orange leaf essential oil against $\boldsymbol{B}$. subtilis.

Several mechanisms have been proposed to explain the antimicrobial activity of essential oils. Its lipophilic compounds can promote damage to cell membrane, which further affects $\mathrm{pH}$ homeostasis and equilibrium of inorganic ions (COWAN, 1999; BURT, 2004). Moreover, they may lead to leakage of cell contents, such as lipids and proteins (OYEDEMI et al., 2009). Our results indicate that the antimicrobial activity of the evaluated essential oils may be largely due to the presence of the oxygenated monoterpenes linalool, 1,8cineole, neral and geranial, which were the main compounds present in four (basil, lemongrass, laurel, and cinnamon leaf) of the five essential oils that presented the strongest antimicrobial potential against the tested bacteria. Moreover, there was a significant correlation $(\mathrm{P}<0.05)$ between the level of oxygenated monoterpenes in the essential oils and MIC and MBC values against E. coli, with $\mathrm{r}$ values of -0.97101 and -0.98561 , respectively. It must be pointed out, however, that minor compounds may also importantly contribute for the antimicrobial activity of essential oils (BURT, 2004).

An interesting aspect related to the antimicrobial activity of essential oils is that the risk of pathogenic microorganisms developing resistance is very low because these products contain a blend of different antimicrobial substances that have different modes of action (BAKKALI et al., 2008; RAHMAN \& KANG, 2009). This is a beneficial characteristic of plantderived products as compared to synthetic antimicrobial agents, as their application in food products may provide better food safety and longer shelf life.

\section{CONCLUSION}

The essential oils of lemongrass, basil, oregano, cinnamon leaf and laurel presented, in descending order, the highest potential for utilization as natural antimicrobial agents in foods. The selection of the essential oil to be applied should take into consideration the pathogens and/or the spoilage microbiota associated to the specific food product.

\section{ACKNOWLEDGMENTS}

The authors are grateful to Fundação de Amparo à Pesquisa e Inovação do Estado de Santa Catarina (FAPESC) (08/ 2009, process FCTP 3302/091), for the financial support of this work. We also thank Dr. Arlei Coldebela for statistical analysis.

\section{REFERENCES}

BAKKALI, F. et al. Biological effects of essential oils. Food and Chemical Toxicology, v.46, p.446-475, 2008. Available from: <http://dx.doi.org/10.1016/j.fct.2007.09.106>. Accessed: Mar. 5, 2012. doi: 10.1016/j.fct.2007.09.106

BURT, S. Essential oils: their antibacterial properties and potential applications in foods - a review. International Journal of Food Microbiology, v.94, p.223-253, 2004. Available from: $<$ http://dx.doi.org/10.1016/j.ijfoodmicro.2004.03.022>. Accessed: Mar. 5, 2012. doi: 10.1016/j.ijfoodmicro.2004.03.022.

CAROVIC-STANKO, K. et al. Composition and antibacterial activities of essential oils of seven Ocimum taxa. Food Chemistry, v.119, p.196-201, 2010. Available from: <http:/ /dx.doi.org/10.1016/j.foodchem.2009.06.010>. Accessed: Mar. 5, 2012. doi: 10.1016/j.foodchem.2009.06.010

CELIKTAS, O.Y. et al. Antimicrobial activities of methanol extracts and essential oils of Rosmarinus officinalis , depending on location and seasonal variations. Food Chemistry, v.100, p.553-559, 2007. Available from: <http://dx.doi.org/10.1016/ j.foodchem.2005.10.011>. Accessed: Mar. 5, 2012. doi: 10.1016/j.foodchem.2005.10.011.

CLSI (Clinical and Laboratory Standards Institute). Performance standards for antimicrobial disk susceptibility tests: approved standard. 8.ed. 940 West Valley Road, Suite 1400, Wayne, Pennsylvania 19087-1898 USA, 2003a. (CLSI document M2-A8 [ISBN 1-56238-485-6]).

CLSI (Clinical and Laboratory Standards Institute). Methods for dilution antimicrobial susceptibility tests for bacteria that grow aerobically; approved standard. 6.ed. 940 West Valley Road, Suite 1400, Wayne, Pennsylvania 19087-1898 USA, 2003b. (CLSI document M7-A6 [ISBN 1-56238-486-4]).

COWAN, M.M. Plant products as antimicrobial agents. Clinical Microbiology Reviews, v.12, n.4, p.564-582, 1999.

ERKMEN, O.; ÖZCAN, M.M. Antimicrobial effects of Turkish propolis, pollen, and laurel on spoilage and pathogenic foodrelated microorganisms. Journal of Medicinal Food, v.11, n.3, p.587-592, 2008. Available from: <http:// online.liebertpub.com/doi/abs/10.1089/jmf.2007.0038>. Accessed: Mar. 5, 2012. doi: 10.1089/jmf.2007.0038.

MILITELLO, M. et al. Chemical composition and antibacterial potential of Artemisia arborescens L. essential oil. Current Microbiology, v.62, p.1274-1281, 2011. Available from: $<$ http://www.springerlink.com/content/q304444560118257/>. Accessed: Mar. 5, 2012. doi: 10.1007/s00284-010-9855-3.

ONAWUNMI, G.O. Evaluation of the antimicrobial activity of citral. Letters in Applied Microbiology, v.9, n.3, p.105108, 1989. Available from: <http://onlinelibrary.wiley.com/ doi/10.1111/j.1472-765X.1989.tb00301.x/>. Accessed: Mar. 5, 2012. doi: 10.1111/j.1472-765X.1989.tb00301.x. 
OUSSALAH, M. et al. Inhibitory effects of selected plant essential oils on the growth of four pathogenic bacteria: $\boldsymbol{E}$. coli O157:H7, Salmonella Typhimurium, Staphylococcus aureus and Listeria monocytogenes. Food Control, v.18, n.5, p.414 420, 2007. Available from: <http://dx.doi.org/10.1016/ j.foodcont.2005.11.009>. Accessed: Mar. 5, 2012. doi: 10.1016/j.foodcont.2005.11.009.

OYEDEMI, S.O. et al. The proposed mechanism of bactericidal action of eugenol, á-terpineol and ã-terpinene against Listeria monocytogenes, Streptococcus pyogenes, Proteus vulgaris and Escherichia coli. African Journal of Biotechnology, v.8, n.7, p.1280-1286, 2009.

PEÑALVER, P. et al. Antimicrobial activity of five essential oils against origin strains of the Enterobacteriaceae family. Acta Pathologica, Microbiologica et Immunologica Scandinavica - APMIS, v.113, p.1-6, 2005. Available from: $<$ http://onlinelibrary.wiley.com/doi/10.1111/j.16000463.2005.apm1130101.x/full>. Accessed: Mar. 5, 2012. doi: 10.1111/j.1600-0463.2005.apm1130101.x.

RAHMAN, A.; KANG, S.C. Inhibition of foodborn pathogens and spoiling bacteria by essential oil and extracts of Erigeron ramosus (Walt.) B.S.P. Journal of Food Safety, v.29, p.176189, 2009. Available from: <http://onlinelibrary.wiley.com/ doi/10.1111/j.1745-4565.2009.00149.x/abstract>. Accessed: Mar. 5, 2012. doi: 10.1111/j.1745-4565.2009.00149.x.

RUNYORO, D. et al. Chemical composition and antimicrobial activity of the essential oils of four Ocimum species growing in Tanzania. Food Chemistry, v.119, p.311-316, 2010. Available from: <http://dx.doi.org/10.1016/j.foodchem.2009.06.028>. Accessed: Mar. 5, 2012. doi: 10.1016/j.foodchem.2009.06.028.

SAS INSTITUTE INC. System for Microsoft Windows, Release 9.1. Cary, NC, 2002-2003. (Cd-rom).

SOKOVIC, M. et al. Chemical composition and antibacterial activity of essential oils of ten aromatic plants against human pathogenic bacteria. Food, v.1, n.2, p.220-226, 2008.

WALSH, S.E. et al. Activity and mechanisms of action of selected biocidal agents on gram-positive and -negative bacteria. Journal of Applied Microbiology, v.94, p.240-247, 2003. Available from: <http://onlinelibrary.wiley.com/doi/10.1046/ j.1365-2672.2003.01825.x/full>. Accessed: Mar. 5, 2012. doi: 10.1046/j.1365-2672.2003.01825.x.

WANNISSORN, B. et al. Antibacterial properties of essential oils from Thai medicinal plants. Fitoterapia, v.76, p.233236, 2005. Available from: <http://dx.doi.org/10.1016/ j.fitote.2004.12.009>. Accessed: Mar. 5, 2012. doi: 10.1016/ j.fitote.2004.12.009. 